\title{
Comment on "Stress Decreases Host Viral Resistance and Increases Covid Susceptibility in Embryonic Stem Cells"
}

\author{
Milad Zandi ${ }^{1,2} \cdot$ Parisa Zeynali $^{3} \cdot$ Ali Rahmani $^{4} \cdot$ Emad Behboudi $^{5}$ \\ Accepted: 27 October 2021 / Published online: 30 October 2021 \\ (c) The Author(s), under exclusive licence to Springer Science+Business Media, LLC, part of Springer Nature 2021
}

\section{Dear editor}

We read with interest a published article by Mohammed Abdulhasan which is published in Stem Cell Reviews and Reports [1]. This article has described the role of stress in host viral resistance and susceptibility to coronavirus disease 2019 (COVID-19) in embryonic stem cells [1].

The authors used COVID-19 as the name of virus, also in this article mistakenly called the SARS-CoV, as COVID-1 and called SARS-CoV-2, as COVID-2 or SARS2. Furthermore, the authors reported coronaviruses have a large genome of $30 \mathrm{mb}, 3$ open reading frames producing 29 proteins, and genomic proof reading [1]. However, according scientific evidence the genome of these coronaviruses is approximately $30 \mathrm{~kb}$. In addition, the authors stated that, of the 7 total and 3 severe human coronaviruses (Cov1, Cov2, MERS), only Cov2 infects both the upper respiratory tract and lungs [1], although MERS-CoV and SARS-CoV can infect both the upper respiratory tract and lungs [2].

Emad Behboudi

emadbehboudi69@gmail.com

Milad Zandi

miladzandi416@gmail.com

Parisa Zeynali

parisazeinali751@gmail.com

Ali Rahmani

rhmn.ali1996@gmail.com

1 Department of Virology, School of Public Health, Tehran University of Medical Sciences, Tehran, Iran

2 Research Center for Clinical Virology, Tehran University of Medical Sciences, Tehran, Iran

3 Department of Biochemistry and Biophysics, Metabolic Disorders Research Center, School of Medicine, Golestan University of Medical Science, Gorgan, Iran

4 Department of Pharmaceutical Biomaterials, Faculty of Pharmacy, Tehran University of Medical Sciences, Tehran, Iran

5 Department of Microbiology, Golestan University of Medical Sciences, Gorgan, Iran
Viruses in Coronaviridae family are considered as enveloped viruses that contain large and single-stranded RNA genomes with ranging in length from 27 to $33 \mathrm{~kb}[3,4]$. Two overlapping ORFs include ORF1a and ORF1b are translated from the genome and generate polypeptides, which are cleaved into 16 nonstructural proteins. Also, these viruses have several other ORFs to encode structural and accessory proteins $[4,5]$.

Acknowledgements The authors would like to appreciate the help of all the participants in this study, especially our colleagues in department of microbiology, Golestan University of Medical Sciences.

\section{Declarations}

Authors' Declaration of Personal Interests None declared.

Declaration of Funding Interests None declared.

\section{References}

1. Abdulhasan, M., Ruden, X., Rappolee, B., Dutta, S., Gurdziel, K., Ruden, D. M., \& Rappolee, D. A. (2021). Stress decreases host viral resistance and increases Covid susceptibility in embryonic stem cells. Stem Cell Reviews and Reports, 21, 1-4

2. Desforges, M., Le Coupanec, A., Stodola, J. K., Meessen-Pinard, M., \& Talbot, P. J. (2014). Human coronaviruses: viral and cellular factors involved in neuroinvasiveness and neuropathogenesis. Virus Research, 19, 194145-58

3. Navand, A. H., Soltani, S., Moghadami, M., Hosseini, P., Nasimzadeh, S., \& Zandi, M. (2020). Diabetes and coronavirus infections (SARS-CoV, MERS-CoV, and SARS-CoV-2). Journal of Acute Disease, 9(6):244

4. Michel, C. J., Mayer, C., Poch, O., \& Thompson, J. D. (2020). Characterization of accessory genes in coronavirus genomes. Virology Journal, 17(1), 1-3

5. Behboudi, E., \& Hamidi-Sofiani, V. (2020). CD147: A missing key in the corona virus disease-2019 (COVID-19). Payesh (Health Monitor), 19(4):467-8

Publisher's Note Springer Nature remains neutral with regard to jurisdictional claims in published maps and institutional affiliations. 